\title{
Supporting and Inhibiting Factors the Application of Diversion Programs to Cases of Child Sexual Violence in the Juvenile Justice System in Indonesia
}

\author{
Setya Wahyudi, ${ }^{*}$ and Angkasa ${ }^{1}$ \\ ${ }^{1}$ Faculty of Law, University of Jenderal Soedirman, Purwokerto, Indonesia
}

\begin{abstract}
Program of diversion in the Indonesian Juvenile Justice System, is intended to support the realization of protection for children, both children of criminal acts, and for children who become victims of criminal acts. Research on the implementation of diversion program, with the method of juridical normative and juridical sociological approach. Research location are Pati, Semarang, Banyumas, Purworejo, Surakarta and Pekalongan. Analysis method used quantitative methods. The results of the research are diversion program through informal mediation is appropriate and can realize the protection of victims of sexual violence, because the penal mediation decision is in the form of: compensation; treatment and psychosocial recovery; responsibility of sexual violence perpetrators; apology from the perpetrator so that the victim's fear will be lost. Factors driving the application of diversified programs, such as conditions of mutual forgiveness between perpetrators and victims. Actors provide compensation, Persuasive support of law enforcement as mediators, religion involvement, youth, social services, psychologists, regret of the perpetrator for the inhibiting factors of the diversion program is that the existence of the desire of the victim for the case forwarded to the court, the parties do not understand the diversion program.
\end{abstract}

\section{Introduction and literature review}

Diversion is the granting of authority to law enforcement officials to take policy actions in handling or resolving problems of offenders - children by not formally completing, among others, to stop or not to continue/release from the court process or to return / surrender to the community and other forms of social service activities [1].

The diversion program in Indonesia is contained in Law No. 11 of 2012 concerning the Child Criminal Justice System (CCJS) which has been effective since July 30, 2014 This CCJS is a legal renewal of the juvenile criminal justice system that is made to meet the needs of the community and the demands of the times. By being effective effectively, institutional readiness is needed; regulatory readiness; readiness of legal culture, as well as supporting facilities for the implementation of the CCJS [2].

*Corresponding author: setyawahyudi_unsoed@yahoo.co.id 
Under the CCJS, the diversion program aims to achieve peace between victims and children; completing Child cases outside the judicial process; avoiding Children from deprivation of liberty; encourage people to participate; and instill a sense of responsibility to the child. The form of the decision on the result of the diversion program agreement can be in the form of: Peace with or without compensation; Society service; Giving back to parents or foster parents; Medical and psychosocial rehabilitation; Take education or training to educational institutions and social institutions. With the existence of diversion programs in the juvenile criminal justice system, it is expected to have the following effects: Reduced number of children entering the criminal justice process, especially Child and Special Care Institution; Increased resolution of child cases by prioritizing Restorative Justice and Diversion; Increased public participation in handling Children Offender; The increasing role of advocates in cases of child cases in court [3].

Sexual violence causes many negative consequences, especially if the victim is a child who still needs time to grow and develop. The acts of violence will surely make an impression and leave the old effects both physically and mentally. Forms of sexual violence are generally carried out by means of coercion and the desire of one party to seduce, poke, hug, squeeze parts of the body, and all kinds of other forms of harassment until the goal is to forcibly intercourse.

Children who experience violence, exploitation, abuse and neglect can face adverse effects, including: Child psychological disorders that result in unstable emotions; Children experience posttraumatic stress aimed at severe stress symptoms such as having nightmares, memories of events that occur repeatedly; Feeling afraid, feeling guilty, feeling lonely, and confused; Decreased confidence; and education problems [4].

The legal system is not only a series of prohibitions or orders, but as a regulation that can support, improve, and regulate a way to achieve goals. The law does not only refer to written regulations or official control from the government, but also concerning unwritten regulations that live in the community, concerning the structure, and regarding the process, so talking about the law will not be separated from the understanding of the legal system as a whole. Someone uses or does not use the law, and obedient or not to the law is very dependent on the legal culture [5].

Law enforcement is a series of processes to describe values, ideas, ideals that are abstract enough to be the goal of the law. Legal objectives or legal ideals contain moral values, such as justice and truth. These values must be able to be realized in real reality. Legal existence is recognized if the moral values contained in the law are able to be implemented or not [6]. Law enforcement is not a stand-alone activity, but has a close reciprocal relationship with the community. Therefore, in discussing law enforcement, discussion should not be ignored about the structure of society behind it. Law enforcement in a society has its own tendencies caused by the structure of the community. The community structure is an obstacle, both in the form of providing social facilities that enable law enforcement to be carried out, as well as providing obstacles that cause law enforcement to be inoperable or poorly implemented [6].

In connection with the law enforcement process, the problem of law enforcement lies in the factors that influence it. These factors are as follows: Legal factors; Factors of law enforcement, namely those who form or apply the law; Factors of law enforcement facilities or facilities; Community factors, as the place where the law applies or is applied; and cultural factors in the form of work, creativity, and a sense based on human intentions in the relationship of life [7]. 


\section{Objective of the study}

This study aims to determine the application of diversion programs in the Indonesian juvenile justice system against cases of sexual violence against children. With the existence of these studies will be analyzed about the supporting factors and inhibiting factors of the implementation of diversion programs on sexual violence cases.

\section{Methodology}

This research is a descriptive study [8], with normative and sociological juridical approaches [9], so that research not only examines the law in the law (law in the book) but also the law in its implementation (law in action). This type of data consists of primary data and secondary data, so the source of this research is legal norms, documents, internet [10], police, judges. Data retrieval techniques with document study/literature study, downloading on the internet, observation and interviews at research locations on snowball informants to get enough answers to answer the formulation of the problem. Central Java Region research location. The collected data is arranged systematically, both in the form of tables and narrative descriptions. Analytical methods with quantitative methods and qualitative analysis to get answers to problem formulation.

\section{Research Results}

\subsection{Application of diversion program in Indonesia}

The Diversion process is carried out through deliberation by involving the Child and his/her parents/Wives, victims and/or parents/Walis, Community Counselors, and Professional Social Workers based on the Restorative Justice approach. In case it is needed, musyawara can involve Social Welfare Personnel, and/or the community. The Diversion Process must pay attention to: the interests of victims; welfare and responsibility of the Child; avoidance of negative stigma; retaliation; community harmony; and decency, decency and public order.

In the application of diversion programs, Investigators, Public Prosecutors and Judges in conducting Diversion must consider: the category of criminal acts; age of the child; results of community research from Bapas; and support for the family and community environment.

The Diversion Agreement must obtain the consent of the victim and/or the family of the Victim's Child and the willingness of the Child and his family. However, there is a diversion that does not require the consent of the victim, namely if: a criminal offense in the form of a violation; minor crime; crime without victim; or the loss value of the victim is not more than the value of the provincial minimum wage.

The results of the Diversity Agreement diversion program agreement made by the Investigator on the recommendation of the Community Advisor can take the form of:
a. Return of losses in the event of a victim;
b. Medical and psychosocial rehabilitation;
c. Return to parents / guardians;
d. Participation in education or training in educational institutions or LPKS no later than 3 (three) months;
e. Community service for a maximum of 3 (three) months.

The results of the Diversion program agreement can take the form of, among others:

a. Peace with or without compensation;

b. Return to parents / guardians; 
c. Participation in education or training in educational institutions or LPKS no later than 3 (three) months; or

d. Society service.

The results of the agreement are outlined in the form of a Diversion agreement. The results of the Diversity agreement are conveyed by the direct superior of the official who is responsible at every level of the inspection to the district court in accordance with his jurisdiction within a maximum period of 3 (three) days after the agreement is reached to obtain the determination. After accepting the determination, the Investigator issues the stipulation on the termination of the investigation or the Public Prosecutor issues the stipulation of termination of the prosecution. Child criminal justice proceedings are continued if: the Diversion process does not produce an agreement; or the Diversity agreement is not implemented.

The number of cases of violence and sexual violence and sexual immorality against children and the number of cases carried out by the diversion program from 2014 to August 2017 in Central Java recorded 69 cases. Of these only 11 cases were carried out by the implementation of the diversion program. Thus there are 58 cases of sexual violence that are not carried out by the diversion program. The application of the diversion program and the implementation of diversion programs against cases of sexual violence is not included in the table as follows:

Tabel 1. Settlement of Cases of Sexual Violence against Children

\begin{tabular}{|l|l|l|l|l|l|}
\hline No. & $\begin{array}{l}\text { Type of Settlement of } \\
\text { Cases of Child Sexual } \\
\text { Violence }\end{array}$ & Obscene & Intercourse & Jumlah & $\%$ \\
\hline 1. & $\begin{array}{l}\text { Diversion Program is } \\
\text { applied }\end{array}$ & 7 & 4 & 11 & $16 \%$ \\
\hline 2. & $\begin{array}{l}\text { Diversion Program is not } \\
\text { applied }\end{array}$ & 15 & 43 & 58 & $84 \%$ \\
\hline & Jumlah & 22 & 47 & 69 & $100 \%$ \\
\hline
\end{tabular}

Source: Police of Central Java Indonesia from 2014 - 2017.

\subsection{Supporting Factors for the application of the diversion program}

The implementation of Diversion in the investigation phase at the research location can be accepted by the investigator. This can be known from the opinions of investigators in the research location, and the investigator has carried out diversions in several cases he handled. The opinion of law enforcers about accepting diversion can be known if there are circumstances like:

a. Perpetrators and victims forgive and be compensated, the cases are often stopped;

b. The child is sorry and promises not to repeat and the parents are able to guide, the case police are stopped and the perpetrator is returned by the parents;

c. The crime is not heavy;

d. The community does not rebel or the environment can accept the child;

e. The perpetrator's parents are able to guide; and

f. The child perpetrator is not a child recidivism [11].

In the practice of family settlement peace in criminal cases is carried out or occurred, because in general the perpetrator or the family of the perpetrator asks the investigator that the case is not processed further. The perpetrators/families of the perpetrators generally have 
compensated the victims, so that this is an attempt to take the heart of the victim so as not to demand further. The victim/family of the victim stated that they had held their own meeting between the victim (the victim's family) and the perpetrator (the family of the perpetrator), and the victim brought a statement about the peace between the victim and the perpetrator. The victim then tells the investigator that there has been a settlement to not continue, or in other words the case is requested to be revoked.

The child case that is carried out by this peace, because there is a condition that between the perpetrator and the victim is usually very familiar so that there is an emotional closeness between the perpetrator/family of the perpetrator and the victim/family of the victim. For this crime of morality in a limited way, namely "Running underage girls", then peace is carried out.

The participation of law enforcers in the settlement of this diversion is in the form of:

a. Investigators (police) bring together the perpetrator and the victim or the victim's family;

b. The investigator gives concessions (time period) to the perpetrator and the victim to conduct deliberations;

c. Investigators will grant or not grant peace between the perpetrator and the victim, will continue to consider the interests or benefits for the community and the real conditions between the perpetrator and the victim;

d. The investigator will stop or not continue the transfer of prosecution at the level of prosecution, if there are circumstances such as:
a) Complaints revoked;
b) Insufficient evidence;
c) Victims have been compensated;
d) Because there are suggestions from community leaders;
e) There is direction from the leader so the case is stopped.

\subsection{Inhibiting factors for implementing the diversion program}

Based on the survey results at the research location, conditions which are factors that tend to be an obstacle to diversion programs are presented in the form of tables as follows:

Table 3. Factors inhibiting diversion in Central Java

\begin{tabular}{|c|l|l|l|}
\hline No. & Factors inhibiting diversion & Amount & Percentage \\
\hline 1 & $\begin{array}{l}\text { The victim's wish for the case to be passed to } \\
\text { court }\end{array}$ & 4 & $12,1 \%$ \\
\hline 2 & $\begin{array}{l}\text { Penalty Penalties for incarceration and more } \\
\text { satisfying victims }\end{array}$ & 5 & $17,3 \%$ \\
\hline 3 & $\begin{array}{l}\text { The parties do not understand the diversion } \\
\text { program }\end{array}$ & 5 & $17,3 \%$ \\
\hline 4 & The parties do not forgive each other & 5 & $17,3 \%$ \\
\hline 5 & Intervention of Legal Counsel & 2 & $6 \%$ \\
\hline 6 & Replace losses is too large & 2 & $6 \%$ \\
\hline 7 & There is no child-specific investigator & 1 & $3 \%$ \\
\hline 8 & $\begin{array}{l}\text { Limited facilities and infrastructure of the } \\
\text { diversion program }\end{array}$ & 1 & $3 \%$ \\
\hline 9 & $\begin{array}{l}\text { The threat of criminal sexual violence is more } \\
\text { than seven years in prison }\end{array}$ & 6 & $18 \%$ \\
\hline 10 & Amount & 31 & $100 \%$ \\
\hline
\end{tabular}

Source: Police of Central Java Indonesia from 2014 - 2017. 
Based on the description in the table, it appears that there are significant obstacles to program diversion, namely: the existence of provisions prohibiting diversion from criminal acts that threaten criminal penalties for more than 7 (seven) years; The desire of the victim so that the case goes to court; There is an assumption that imprisonment to deter victims is more satisfying; The parties do not understand the diversion program; the parties do not forgive each other; and can occur because the compensation is too large, so the perpetrator is unable to pay compensation.

Observation in practice is known, that in fact the police (investigators) also want not to always want to delegate the child's case to the prosecutor's office. However, if the legal counsel intervenes so that the case requires a formal examination, the investigator does not diversify the case.

Efforts to stop a child's case will be severely hindered if the investigator has detained the child perpetrator. The perpetrator of the child who is detained indicates an indication: a serious crime; the victim feels very disadvantaged; for the security of the perpetrator for the act of playing a judge by the community, or the crime makes the community uneasy. In addition there is doubt for investigators to stop the investigation of children, because there is a pretrial institution, which will correct whether or not the termination of the investigation is correct.

Against child perpetrators who have been temporarily detained, the police and public prosecutors, at the research location have never been to stop the investigation, and continue to forward or hand over to the public prosecutor. Reasons for investigating detention of child offenders, on the grounds of crimes committed include serious crimes and detention for the safety of children and to facilitate examination. The investigator states that he will continue to conduct investigations and will hand over to the prosecution if the child perpetrator has been detained, and the crime committed is threatened with imprisonment exceeding 7 (seven) years, such as criminal acts of sexual violence against children.

\section{Discussion}

The conditions found in children as perpetrators of crimes vary. Therefore the factors that can be considered for diversion need to be observed. Some of the situation factors that are considered as the implementation of the diversion idea can be stated as follows.

a. Nature and condition of action.

b. Previous violations committed.

c. Degree of involvement of children in cases;

d. The child's attitude towards the action. If the child acknowledges his actions and regrets, this becomes a positive consideration for diversion. The implementation of diversion cannot be considered if the child does not acknowledge his actions;

e. Reaction of the parents and/or family of the child to the act. The support of parents/family is very important so that diversion can be successful. If the family covers up the child's actions, then an effective diversion plan will be difficult to implement;

f. The proposal is given to make repairs or apologize to the victim. An apology to the victim is a clear indication for the victim that the child wants to be responsible for his actions. If the child is not ready to apologize for his actions, then diversion is difficult;

g. Impact of actions on victims. If crime has a very serious impact on the victim, even if the child does not intend to do so, then diversion may not be an option;

h. The victim's view of the treatment method offered. For diversion to be planned properly, there must be input and / or agreement with the victim;

i. Impact of sanctions or penalties previously received on children. If the child has been dealing with the law beforehand, and the sanction was not responded positively by the 
child, then the diversion is not an option, unless the offense was classified as mild or has happened for a long time;

j. If in the public interest, the legal process must be carried out. The police must consider the public interest in addition to the interests of victims, children and their families. In certain cases, there are high demands from the public for criminal proceedings, because children have made people nervous. Under these conditions diversion is not carried out.

A prominent inhibiting factor is the reason the parties did not implement the diversion program, namely the condition of the victim who cannot forgive the perpetrator's actions, the will of the victim so that the perpetrator is subject to criminal sanctions, compensation that does not satisfy the victim. This condition causes the victims of sexual violence to refuse or insist on accepting the diversion program. Imprisonment of prison sentences for perpetrators of sexual violence still satisfies the victims.

The application of this diversion program will be difficult to implement if the community is still entrenched in the retributive justice. This is evident in the research location, the community is still many and thick in the face of justice in retaliation. The principle of justice in retaliation is contrary to the purpose of implementing the diversion program. The diversion program prioritizes to implement the principle of improving justice (restorative justice). The community and victims of sexual violence will feel satisfied if the perpetrators of sexual violence are subject to imprisonment. This desire is due to the view of the desire for revenge against the perpetrator of the crime. Communities and victims will be more satisfied if the perpetrators of criminal acts are retaliated in the form of imprisonment.

The police, prosecutors and judges consider the legal provisions to be able to implement the diversion program. Based on the provisions of Article 7, 8 and Article 9 of Law No. 11 of 2012 concerning SPPA. The diversion program can only be applied to criminal acts that are subject to imprisonment under 7 (seven) years and a criminal act that is not a repeat of a criminal act. The provisions of Article 8 of the UUSPPA stipulate that the Diversion Process must pay attention to: the interests of victims; welfare and responsibility of the Child; retaliation; community harmony; and decency, decency and public order. It is not easy to be able to fulfill these considerations. If one of the considerations is not met, then the divers program will not be carried out. The provisions of Article 9 of the UUSPPA stipulate that in the application of the diversion program law enforcement must consider: the category of criminal acts; age of the child; results of community research from Bapas; and support for the family and community environment.

Such provisions will always be the main consideration of law enforcement to be able to implement or not implement the diversion program. This provision forces law enforcement in practice to be the reason for not having the courage to implement the diversion. It is not surprising that the provisions on the prohibition on the application of the diversion program are still the dominant reason.

Data in the field turns out that there is an application of a diversion program carried out by the police. The prohibition on the application of this diversion program, was violated by the police or violated by the discretionary authority of the police. Discretionary authority is enforced in connection with the Republic of Indonesia National Police Law (Law No. 2 of 2002). The police based on the interests of child protection, carry out discretionary policies in the settlement of cases of sexual violence against children.

The authority of police discretion is different from the diversion program. Discretionary authority is owned by the police as law enforcers to act according to their policies and views with consideration of public order and does not conflict with morality, while the application of the diversion program is dominated by the wishes of the victims or the community, so that if the victim does not approve the application of this diversion, the application the diversion program cannot be applied. It is not easy to equate views between victims, perpetrators and the community, so the application of diversion is not easy. 
Sexual violence is a crime that is categorized as a serious crime. This is seen in the provisions of Article 81 and Article 82 of Law No. 35 of 2014. Criminal threats to perpetrators of sexual violence and obscene violence against children, namely a short prison sentence of 5 (five) years and a maximum of 15 years and a maximum fine of 5,000,000,000, -(five billion rupiah). Thus it becomes clear that the crime of sexual violence is a serious crime. This normative condition causes law enforcers not to implement diversion programs.

Based on the results of the study, the implementation of diversion required several conditions to support and support the application of the principle of restorative justice, namely: the condition of the child perpetrator; category of criminal acts committed by children; condition of victim of child crime; and support of parents / guardians and their families [12].

The age of the perpetrator of the crime, the younger the age of the perpetrator, the more important it is to complete the settlement with a restorative justice approach. The age of child criminal responsibility in Indonesia according to the Law of the Child Criminal Justice System is 12 years, meaning that no child under 12 (twelve) years of age can be held criminally liable for committing a crime. If there are children under 12 (twelve) years of committing a crime, it is indicated that a very serious problem has occurred, even though the child actually does not understand the consequences of the action. For handling cases like this, the settlement through the judicial process will not be effective, therefore it needs to be handled by competent institutions or agencies by referring to educational institutions, social services or related community institutions. In certain conditions, children aged between 12 (twelve) years to 14 (fourteen) years can be processed through formal law, but cannot be subjected to detention or imprisonment. For groups of children under 12 (twelve) this year, handling with a restorative justice approach must be the first priority. Children over the age of 14 (fourteen) can be processed through a formal legal process, even though handling with a restorative justice approach must be a first priority and imprisonment is the last resort.

Completion with a restorative justice approach will be effective if the child acknowledges the act and regrets it. Completion with a restorative justice approach cannot be considered if the child does not recognize the act and does not regret it.

Completion with a restorative justice approach must pay attention to the child's condition when committing a crime. If the driving factor of a child committing a crime is beyond the control of the child and/or child to commit a crime for the first time, then the settlement with a restorative justice approach is done by mediation or family deliberation, involving the victim, the perpetrator and his/her family is the primer priority.

The category of criminal acts that are threatened with criminal sanctions of more than 1 (one) year and up to under 7 (seven) years and not a repetition of crimes are prioritized to be resolved by a restorative justice approach, by means of mediation or family deliberation involving the victim, perpetrator and his family.

Children who have committed a crime for the first time should be prioritized to be resolved with a restorative justice approach, by means of mediation or family deliberation, involving the victim, perpetrator and his family.

Every crime will have a different impact on each victim. Losses suffered by victims due to criminal acts can be physical, psychological, material and social which can have a serious impact on victims. Thus the victim needs a different response to the same crime. For cases that have a serious impact on the victim, the consent of the victim is needed in the settlement of child cases. However, for cases that do not have a serious impact on the victim, no victim approval is needed in the settlement of a child case. Diversion agreements must get the consent of the victim and/or the family of the Child Victim and the willingness of the Child and his family, except for: a criminal offense in the form of a violation; minor crime; crime without victim; or the loss value of the victim is not more than the value of the provincial minimum wage. 
Handling child cases of perpetrators of criminal acts of support from parents/guardians and families is very important, so that a restorative justice approach can succeed. The parent/guardian or family of the child needs to be actively involved in the settlement of cases, rehabilitation programs and reintegration.

If the family (parent/guardian) is not actively involved, then the settlement plan with an effective restorative justice approach will be difficult to implement. Families may feel ashamed of the child's actions so that they cover up the child's mistakes. If there is a parent or family like this, the relevant party must give understanding to the parent or family about the need for family support. If the parents of the perpetrator and the victim's family cannot reach an agreement, then the model of restorative justice through the diversion program can cause failure [13].

The implementation of diversion programs in the application of restorative justice in practice still faces many obstacles, both obstacles from substantial aspects, structural aspects as well as cultural aspects, as follows: Substantial obstacles, namely until now there is no standard instruction for the police to implement restorative justice, so that the police are only based on discretionary authority to prioritize the best interests of children according to the police. Restrictions on the types of criminal acts that can be carried out by the application of restorative justice indicate that the law has not been fully in favor of the best interests of the child. The principle of retribution for deeds remains a scourge for children to continue to get evil stigma on children. It is difficult to prevent children from retributive justice when children commit serious crimes [14].

Structural obstacles, namely the ability of the apparatus as a mediator greatly influences restorative justice success. The granting of this authority caused the police to be too easy to surrender the cases they handled in the mediation process. The police have not all provided child-specific investigators.

Cultural barriers involving public trust in restorative justice policies are very important. Therefore, the implementation of restorative justice must have mutual agreement between law enforcers and the parties, and take the best action for children. People are still pessimistic that this restorative justice policy can cause the apparatus to harm the interests of certain parties. The application of restorative justice is still severely hindered by the views of enforcers and communities who are still rooted in the aim of retaliation for the evil acts of child perpetrators, so that there is still a desire to impose a crime solely expected to deter children.

The legal system is not only a series of prohibitions or orders, but as a regulation that can support, improve, and regulate a way to achieve goals. The law does not only refer to written regulations or official control from the government, but also concerning unwritten regulations that live in the community, concerning the structure, and regarding the process, so that talking about the law will not be separated from the understanding of the legal system as a whole. Someone uses or does not use the law, and obedient or not to the law is very dependent on the legal culture [15].

Legal culture refers, then, to those parts of general culture-customs, opinions, ways of doing and thinking that social forces to ward or away from the law and in particular ways (legal culture is the atmosphere of social thought and decisive social power how the law is used, avoided, or misused).

The work of law in society involves several elements or aspects that are interrelated as a system. Some of these aspects are: Law Making Institutions, Sanction Activity Institutions, Role Occupants and Societal Personal Forces, Legal Culture, and elements Feed Back from the process of running the law [16].

Speaking of the work of law or law enforcement, in terms of law enforcement here is related to two things, first, what is to be done/enforced. Second, what is the law to be enforced. The law contains abstract ideas such as justice, usefulness and certainty. The 
abstract idea is then embodied or formulated in a rule (both written and unwritten). The work of law or law enforcement means related to the effort to realize the abstract idea. In the modern state, efforts to realize the idea are carried out through an agency called law enforcement agencies.

Law enforcement is a series of processes to describe values, ideas, ideals that are abstract enough to be the goal of the law. Legal objectives or legal ideals contain moral values, such as justice and truth. These values must be able to be realized in real reality. Legal existence is recognized if the moral values contained in the law are able to be implemented or not [17]. Law enforcement is not a stand-alone activity, but has a close reciprocal relationship with the community. Therefore, in discussing law enforcement, discussion should not be ignored about the structure of society behind it. Law enforcement in a society has its own tendencies caused by the structure of the community. The community structure is an obstacle, both in the form of providing social facilities that enable law enforcement to be carried out, as well as providing obstacles that cause law enforcement to be unworkable or poorly implemented.

\section{Conclusion}

a. The application of the diversion program in the juvenile justice system in Indonesia has cultural support, namely forgiving each other between perpetrators and victims, persuasive support from law enforcers as mediators, religious leaders and community leaders.

b. The application of sexual violence against children through diversion programs in the juvenile justice system in Indonesia still experiences substantial and cultural barriers, as well as financial barriers, as follows:

1) Substantial obstacles, namely the threat of criminality for sexual violence exceeds 7 (seven) years of imprisonment, and

2) Cultural barriers are still dominant in the desire for revenge / reward on the victim and the community.

3) Financial barriers are the disagreement between the perpetrator and the victim with compensation that cannot be fulfilled by the perpetrators of sexual violence.

The implementation of Diversion in the investigation phase at the research location can be accepted by the investigator. This can be known from the opinions of investigators in the research location, and the investigator has carried out diversions in several cases he handled. The opinion of law enforcers about accepting diversions can be known if there are circumstances such as:

a. perpetrators and victims forgive and be compensated, the cases are often stopped;

b. the child is sorry and promises not to repeat and the parents are able to guide, the case police are stopped and the perpetrator is returned by the parents;

c. the crime is mild;

d. the community does not rebel or the environment can accept the child;

e. the perpetrator's parents are able to guide; and

f. the child perpetrator is not a child recidivism 


\section{References}

1. Rules Rule 11.1, 11.2 dan 17.4 United Nations Standard Minimum Rules for the Administration of Juvenile Justice (SMRJJ ) -"The Beijing Rule.

2. S. E. Wibowo, jli, 13, 2, (2016)

3. H. Harkrisnowo, "Renewal of the Juvenile Justice System," Criminal Law and Criminology Training; Principles of Criminal Law and Criminology and Its Development, Gajah Mada University, Yogyakarta, 23-27 February 2014.

4. S. Pusporini, Application of the Restorative Justice Principle in the Crime of Sexual Violence Done by Child Actors (Study in the Legal Area of Banjarnegara District Police and Purbalingga Regional Police), p. 53, (Thesis, Magister of Law Faculty of Law University of Jenderal Soedirman, 2016)

5. E. Warassih, Pranata Hukum Sebuah Telaah Sosiologis, p. 82. (PT. Suryandaru Utama, Semarang, 2005)

6. S. Rahardjo, , Penegakan Hukum, Suatu Tinjauan Sosiologis, p. vii., (Genta Publishing, Yogyakarta, 2009)

7. S. Soekanto, , Faktor-faktor yang Mempengaruhi Penegakan Hukum p. 8, (PT. Raja Grafindo Persada, Jakarta, 2007)

8. This research was funded by Directorate of Research and Community Service Directorate General of Strengthening Research and Development Ministry of Research, Technology and Higher Education in accordance with the Research Contract Number : 068/SP2H/LT/DRPM/IV/2017 entitled "Diversion Model Against Sexual Violence Crime Case as an Effort to Realize the Juvenile Justice System That Protects Children Victims of Sexual Violence".

9. Amiruddin dan H. Z. Asikin, Pengantar Metode Penelitian Hukum, hlm. 118-131 (PT Raja Grafindo Persada, Jakarta, 2004)

10. J. Ibrahim, Teori \& Metodologi Penelitian Hukum Normatif, p, 323, (Bayumedia Publishing, Malang, 2006)

11. Interview results at the research location

12. N. A. Said and S. Wahyudi, Penerapan Keadilan Restoratif (Restorative Justice)Terhadap Penyelesaian Tindak Pidana Yang Dilakukan Oleh Anak, p. 40- 41, (Institute for Research and Community Service, Jenderal Soedirman University, Purwokerto, 2015) See M. Taufik Makarao, Pengkajian Hukum tentang Penerapan Restoratif Justice dalam Penyelesaian Tindak Pidana yang dilakukan oleh Anak-anak, p.114-118 (National Law Development Agency, Ministry of Law and Human Rights RI, Jakarta, 2013)

13. H. Abdurrahman, F. A. Sudewo, D. I. Permanasari, JDH 16, 1, P.p. 54 (2016),.

14. N. Aziz Said and Setya Wahyudi, Op. Cit. p. 63-64

15. E. Warassih, Pranata Hukum Sebuah Telaah Sosiologis, p.82, (PT. Suryandaru Utama, Semarang, 2005)

16. L. M. Friedman, The Legal System, A Social Science Perspective, p.14-15. (Russel Sage Foundation, New York, 1975)

17. Satjipto Rahardjo, Penegakan Hukum, Suatu Tinjauan Sosiologis, p.vii. (Genta Publishing, Yogyakarta, 2009) 